\title{
Inter-Parliamentary Cooperation: The Next Frontier in Global Politics
}

\author{
Shaker Ahmed Alshareef \\ Freelance Researcher, United Kingdom. E-mail: sama999@gmail.com \\ Received: September 27, 2021 \\ Accepted: October 162021 \\ Online Published: November 25, 2021 \\ doi:10.11114/ijlpa.v4i2.5410 \\ URL: https://doi.org/10.11114/ijlpa.v4i2.5410
}

\begin{abstract}
National parliaments have become significantly active in international arena particularly in advancing democracy and national interests within a globalized context. This report assesses the role that inter-parliamentary organizations play in regional and global political scenes under the umbrella of the Inter-Parliamentary Union (IPU). The article views these regional institutions in the context of their relations to the IPU through content analysis of available literature. Three of the regional bodies of interest in the report are the Arab Parliament, Central American Parliament (PARLACEN), and the European Union Parliament. The findings drawn from available literature shows that these organizations have become the new frontier for political movements as they take center stage in global affairs. The objectives of these regional bodies are largely aligned with those of the IPU, and it is not surprising that they frequently collaborate or agree on several issues. The article concludes that the Inter-parliamentary diplomacy and the pursuit of democracy through collective efforts of regional parliamentary bodies have made it possible for IPU to have a higher political currency in different jurisdictions.
\end{abstract}

Keywords: Charter, Cross-national, Jurisdiction, Global ecosystem, Policy areas.

\section{Inter-Parliamentary Cooperation}

States cannot exist in isolation today because most of the challenges they face require global solutions. A democratic nation with enough resources to take care of its citizens is still concerned about the affairs of its neighbors because the instability and the challenges of the neighbor could directly impact its wellbeing. The classical sense of states in the $19^{\text {th }}$ century separated the internal issues and its relationship with other states. All states had their own rule and model of governance (most states way was similar). Interference from external entities was largely frowned upon because that was seen as an attack on people's autonomy and way of life in that state. Under the classical gage, only the government of the state-initiated foreign relations with other states. The governments enjoyed a monopoly over foreign relations. Envoys appointed by the government would represent the states in their relations with other nationalities. The jurisdiction of parliaments was limited within the nation. Their primary role was to pursue policies that would positively impact their constituents. It was an offense against the principle of sovereignty for parliament to engage in foreign affairs. The formulation of the national parliament is often founded on the principle that it is a people representation in government. Government engages in many pursuits, including diplomacy and foreign relations. Ideally, parliament should be engaged in foreign relations under these conditions. However, the tradition of diplomacy and foreign relations has been driven by complex networking and bureaucracy, which is seen as an area under the purview of the central government or the executive. Modern cross-national and global relations have seen parliaments become central in global relations ecosystems as they seek to advance common goals and propagate democratic ideals.

The growth of inter-parliamentary cooperation goes as far as 1889 when the Inter-Parliamentary Union (IPU) was formed. Before its formation, there existed no conventional means through which governments and parliaments could work together on international issues. IPU was a vision of an Englishman William Randal Cremer and a Frenchman Frédéric Passy (IPU, 2021). These two formulated a vision that became the foundation of IPU. The two established an association that has been followed to date. Today, the IPU is a thriving global organization that brings together the parliaments of many nations to pursue collective objectives to better their nations. The two men with different social and political backgrounds believed that peaceful arbitration could solve international disputes. Thus the primary vision of IPU was to foster global peace. That vision has persisted in presenting years where the organization continues to advocate for global peace. The work of William Randal Cremer Frédéric Passy led to the establishment of the original inter-parliamentary cooperation and founded the first multilateral cooperation that occurred between different national parliaments (IPU, 2021). The IPU has gone to embody the first vision. One of its notable contributions was in the Permanent Court of Arbitration in The Hague in 1899. The IPU was also among the proponents for forming the League of Nations in 1919 and 
the United Nations in 1945 (Chiniaeva, 2021). Parliaments will continue to act internationally to ensure that the conduct of governments is put under tight scrutiny. The modern democratic space provides a platform for international cooperation of parliaments from different nations as long as such cooperation does not pose any significant threat to national interests. Parliamentary cooperation may pose a risk to states that are not fully democratic or those that are authoritarian. Part of the cooperation is therefore tasked with ending such regimes and advancing democracies in such states.

\section{Methodology}

This report is based on information gathered from literature on IPU and regional parliamentary unions. A thematic analysis provides a model through which the predominant themes in the parliamentary cooperation's are established. A thematic analysis provides a similar means for understanding data as any other theory grounded in ethnography and phenomenology would. A thematic analysis has provided a foundational method for qualitative analysis that has been undertaken in this report. A rigorous thematic analysis has provided insightful findings into the working of IPUs and regional parliamentary bodies. The literature has provided an understanding of how the parliamentary unions advance their agenda globally and how they are centrally engaged in policies and pursuits that were traditionally left to central governments of nations.

\section{The IPU}

The IPU is a global institution consisting of several domestic parliaments. The organization is very close to universal coverage, and it currently has 179 members out of 193 members in the world. Its membership is from large countries like China and India to small nations like San Marino and Palau. Its membership represents over $80 \%$ of the world's population (Wagner, 2019). The organization has grown from a small entity to a large, influential organization focused on advancing democracy, equality, human rights peace, and sustainable development. The similarity between his goals and those of the united nations has seen it work with the global body on several occasions (Stout \& Love, 2018). The members drawn from many different cultures, political leanings, and national interests work together to foster positive change in their nations and other countries. The body is open to all national parliaments legally established and operate in states recognized by the United Nations. There are instances where members have been suspended because of an unconstitutional dissolution of parliament. Others have been suspended due to the non-payment of the expected contribution. Re-admittance, admitting, or suspension of members' decisions are taken by the organization governing council. The organization also has 13 associate members that are drawn from national groupings and associate organizations (Chiniaeva, 2021). Two of the most important associations that are members of the union are the Arab Parliament, the Central American Parliament (PARLACEN), and the European Parliament. Other associates include; Andean Parliament, East African Legislative Assembly (EALA), Inter-Parliamentary Assembly of Member Nations of the Commonwealth of Independent States, Inter-Parliamentary Committee of the West African Economic and Monetary Union (WAEMU), Latin American and Caribbean Parliament (PARLATINO), Parliament of the Central African Economic and Monetary Community (CEMAC), Parliament of the Economic Community of West African States(ECOWAS), Parliamentary Assembly of La Francophonie (APF), Parliamentary Assembly of the Council of Europe (PACE) and Parliamentary Assembly of the Black Sea Economic Cooperation (PABSEC) (Wagner, 2019).

\subsection{Arab Parliament}

The idea of an Arab Parliament had been in discussion by the Arab League from as far as the mid-1950s. However, it was initially impossible to form such a body because it ran contrary to the Leagues founding charter, which had no mention of the direct representation of citizens from the Arab world. Numerous efforts to amend this charter ended up creating the Arab Inter-Parliamentary Union (AIPU) in 1977. AIPU was not a constituent of the Arab League (Abdulhameed, 2019). Still, it focused on acting as a forum through which policies between different Arab parliaments could be coordinated. Efforts to make an inter-parliamentary unit that would work within the framework of the Arab League persisted. In the 80s, AIPU and the secretariat of the Arab league worked together to form this body. During the $17^{\text {th }}$ General Conference, which took part in Algiers in March 2005, the Arab League amended its charter to include an Arab Parliament (AP) as an official affiliate of the Arab League (Ahmad, 2016). The primary objective of AP was to give the Arab world a voice besides that of the Arab government and strengthen the democratic space within the region. The Arab Parliament has transformed into a significant factor in the global political sphere. The evolution of the traditional parliamentary role from formulation of policies and control of the government to other non-traditional responsibilities such as the merging of nations via parliamentary diplomacy has made AP a very powerful entity in the Arab world (Fawcett, 2016). AP has been a crucial voice in addressing the Arab spring, the Syrian crisis, and the Israel- Palestine crisis.

The immigration crisis. AP works closely with IPU in addressing issues that impact citizens of the Arab world and the rest of the world. A recent demonstration of this union occurred in June 2021 when the Arab Inter-Parliamentary Union stood against the European Union resolution against Morocco (Richter, 2021). The EU had slammed morocco over the 
immigration crisis in Ceuta. The Arab Parliament and Pan-African Parliament (PAP) protested against the EU vilification of Morocco's handling. The AP contended that the EU had ignored the principles of good diplomacy and parliamentary standards between countries, which were based on dialogue, understanding, common interest, and mutual respect (Richter, 2021). There were claims that Spain was outsourcing political challenges instead of a bilateral framework with Morocco. The IPU and AP accused the EU of facilitating unwarranted actions against a sovereign state. The actions were antagonizing to Arab countries. AP and the Arab IPU pledged full support to Morocco in the standoff with Spain (Richter, 2021). These actions are just illustrative of the political clout possessed by the regional and the global Inter-Parliamentary Union. Morocco is significantly less powerful than the EU. However, it is considerably strengthened by the united voice of AP and IPU. The inter-parliamentary cooperation shifts geopolitical influence and power to the members they are protecting in any given instance (Moure, A. M. (2019).

\subsection{Central American Parliament (PARLACEN)}

The Central American Parliament, also known as Parlamento Centroamericano (PARLACEN), is the Central American Integration System (SICA) and is headquartered in Guatemala. The founding of PARLACEN can be traced back to the 1980s, when Contadora sought solutions to the civil wars that plagued Nicaragua, El Salvador, and Guatemala (Albarrací, 2013). While the group dissolved in 1986, the idea that the region should have a common body with significant political clout and influence persisted, leading to the formation of the Esquipulas II Agreement. It was this agreement that led to the creation of the Central American Parliament and other political bodies (Luciano, 2017). Several roles were given to this new political body.

1) The PARLACEN would act as a consultative body in common economic, social and political issues and find ways of advancing the cultural and security issues that predominate in central America.

2) The body was also expected to draft treaties and agreements that contribute to fulfilling the needs of the areas under negotiation in the Central American Areas.

3) PARLACEN was also mandated to promote peaceful coexistence and security in the region.

4) The institution would also advance democracy, pluralist and participatory systems of governance in the Central America region based on standards acceptable in the International Laws (Mignolo, 2018).

5) Its founding members also wanted an institution that would strengthen and increase the validity of international law.

6) The body would recommend, advise, and provide consultative services to Central American governments on matters within its jurisdiction (SICA, 2021).

PARLACEN has been vital in the process of democratic socialization. The institution has played a significant role in consolidating harmony in the jurisdiction. Central America was one of the most violent places during the cold war. The most significant involvement of PARLACEN was to advance peace and stability in the region (Costa et al., 2013). Presently, the organization has brought together past guerilla fighters and military men that clashed on opposing positions during the armed struggles. The body has enabled the institutionalization of dialogue that has contributed to the sustenance of democracy in the region. Members from specific parties with different political ideologies now resort to dialogue and political negotiation instead of armed struggles. A similar interaction is also accurate for members drawn from different nationalities (Luciano, 2017). PARLACEN provides a means through which the region can tackle common political issues plaguing the region. The region's parliamentary body also has been central in improving the economies of individual states by advocating for progressive economic measures and working with governments to draft economic policies that improve the local economies. The IPU works with PARLACEN because the body embodies and pursues a similar objective to its own (Albarrací, 2013). PARLACEN and IPU are both focused on peace and democracy and improving conditions for the marginalization of minority groups.

\subsection{European Parliament}

The European Parliament (EP) is one of the most associated members of IPU owing to its political, financial, and geopolitical influence. This parliament is the legislative branch of the European Union consisting of 705 directly elected members from all EU countries. The parliamentary body makes decisions that form part of EU legislation, including budgetary allocations and EU state governors (Hodson \& Peterson, 2017). The EP also monitors and holds into account other EU institutions such as the Europe Commission. The EU parliament was established in 1958 as a common assembly made up of members selected by EU countries. From 1979 each member was selected through universal suffrage for a five-year term. The number of members varies from country to country. Nations such as Italy, France, the UK, and Germany have over 70 members. Smaller nations like Cyprus, Estonia, Luxembourg, and Malta have less than 7 (Hodson $\&$ Peterson, 2017). The members of parliaments are drawn from different political affiliations. The vast majority are linked to seven transnational political groups. The largest transnational groups include the Europeans Peoples Party, which identifies itself as Christian Democrat, The Progressive Alliance, Socialist and Democrats, and The Alliance of 
Liberals and Democrats for Europe (Auel \& Christiansen, 2015). Unlike other Inter-Parliamentary Union, The EU parliament is deeply political. Matters are often solved through party lines on several occasions. It is an embodiment of democracy and pluralism that is present throughout many nations in the European Union.

The general assembly of the EU parliament meets annually for a 12 one-week session in the city of Strasbourg, France. Most of its business is conducted through its committees which meet in Brussels (Hodson \& Peterson, 2017). This parliament is divided into several specialized committees tasked with different issues such as foreign affairs, agricultural issues, budgetary issues, monetary and fiscal policies, the rights of minorities, labor and employment, regional politics, and the environment. Temporary committees may also be formed at any given time to address issues that arise. The EU parliament has a secretariat that assists it in its work. Much of the work conducted by the secretariat is usually to translate and interpret between the 23 official languages used by members of the union. The power exercised by this body has substantially risen over the years (Palle \& Richard, 2021). The role of the parliament was initially limited to consultation. With more integration, the assembly has earned significant power, including the power to veto some policies, particularly in economic concerns. The growth of this power is traced back to the Lisbon treaty that was signed in 2009, which allocated increased legislative powers to the parliament (Musliu, 2011). The power of parliament to make decisions together with the Council of the European Union was broadened to many other policy areas.

The EUs parliament's most significant influence towards the ideals advanced by the IPU is to put checks on other EU institutions. Most countries that form the EU are the traditional powerhouses that advanced imperialism and participated in World Wars. These nations have a collective geopolitical influence that sets them apart from any other regional bodies. The EU parliament is, therefore, an important associate of IPU because it can keep the EU in check, especially with relation to its interactions and association with other weaker states. The EU parliament can remove the president of the European Commission, which is the executive branch of the commission, through a two-thirds majority vote (Auel \& Christiansen, 2015). In 1999, the commission faced with such a vote opted to resign, an occurrence that demonstrated the might of the EU. The most important role of the EU is to supervise and control the powers held by other institutions affiliated to the EU and which have significant power that could determine the freedom, democracy, political wellbeing, and the liberties enjoyed in many other nations impacted by the EU influence (Kinski, 2020). Two such institutions are the European Court of Justice and the European central bank. Together with the council of ministers, parliament may request the court to establish special courts to address certain disputes. For instance, in 2005, a special tribunal was established to settle disputes between civil servants (Auel \& Christiansen, 2015). The European Parliament also guides the European Central Bank. Parliament may question or censor the monetary policies adopted by the institution.

The European Union Parliament is complementary to the IPU and has on numerous occasions stood in support of the determinations made by the IPU. The union is considered one of the most important associates of the IPU. The cooperation between IPU and the EU parliament manifested itself in 2008 when the EU mooted establishing the United Nations Parliamentary Assembly (UNPA) (Yost, 2020). The Brussels Assembly sought consensus on the connections between UNPA and IPU and the potential roles and mandates of the parliamentary organizations. The EU parliament argued that the two institutions would complement and that UNPA would not replace or duplicate IPU functions. UNPA would seek to fill the gaps unmet by IPU, which included responding to the democratic deficit in governance. The EU Parliament noted that the IPU was a group of national parliaments. Its activities were limited to providing a parliamentary aspect in international alliances. Its primary role was to reinforce national parliaments to provide oversight and presentations in their domestic jurisdictions on issues of international importance (Benz, 2017). UNPA would directly exercise parliamentary functions in the global platforms. A primary objective would be to make UN executives accountable to a "global" parliamentary body. The IPU had no such jurisdiction. While the IPU facilitates national parliaments, UNPA members would be focused on a global perspective (Yost, 2020). The IPU would be involved in the formation of UNPA The IPU was central in the pursuits of the EU parliament, highlighting how the organization was central to both domestic and international politics.

\section{Conclusions}

Modern cross-national and global relations have seen parliaments become central in global relations ecosystems as they seek to advance common goals and propagate democratic ideals. The modern democratic space coupled with the globalization of domestic politics has functioned to create an environment where Inter-Parliamentary cooperation has earned significant utility in pursuing global policies and politics. The IPU is at the center of the new school of global parliamentary politics. The organization brings many national assemblies together to pursue a common purpose. While many regional parliamentary associations bolster the work of IPU, the three notable ones in recent years have been the EU parliament, The Arab Parliament, and Parlamento Centroamericano (PARLACEN). AP works closely with IPU in addressing issues that impact citizens of the Arab world and the rest of the world. AP has been a crucial voice in addressing the Arab spring, the Syrian crisis, and the Israel- Palestine crisis. The IPU works with PARLACEN because the body embodies and pursues a similar objective to its own. PARLACEN and IPU are both focused on peace and 
democracy and the improvement of conditions for the marginalization of minority groups. The European Union Parliament is also an important association that bolsters the efforts of IPU in advancing democracy and ensuring that members of the European Union abide by the aligned ideals of IPU and the EU parliament. The cooperation of these institutions has provided political machinery that advances democracy and liberty globally.

\section{References}

Abdulhameed, M. A. (2019). Measuring the Arab Parliament's institutional development. Review of Economics and Political Science. Retrieved from https://doi.org/10.1108/reps-06-2019-0079

Ahmad, A. Y. (2016). Introduction to a general reading of the Arab scene. Contemporary Arab Affairs, 9(4), 493-510. Retrieved from https://doi.org/10.1080/17550912.2016.1201932

Albarrací n, J. (2013). Integration Parliaments in Latin America: The Cases of Parlandino and Parlacen. Parliamentary Dimensions of Regionalization and Globalization: The Role of Inter-Parliamentary Institutions, 109-125. Retrieved from https://doi.org/10.1057/9781137322746.0012

Auel, K., \& Christiansen, T. (2015). After Lisbon: national parliaments in the European Union. West European Politics, 38(2), 261-281. Retrieved from https://doi.org/10.1080/01402382.2014.990693

Benz, A. (2017). Patterns of multilevel parliamentary relations. Varieties and dynamics in the EU and other federations. Journal of European Public Policy,24(4), 499-519. Retrieved from https://doi.org/10.1080/13501763.2016.1273371

Chiniaeva, A. (2021). Inter-Parliamentary Union. In Parliamentarization of International Governmental Organizations (pp. 41-52). Springer, Cham. Retrieved from https://doi.org/10.1007/978-3-030-71341-6_4

Costa, O., Dri, C., \& Stavridis, S. (Eds.). (2013). Parliamentary dimensions of regionalization and globalization: the role of inter-parliamentary institutions. Springer. Retrieved from https://doi.org/10.1057/9781137322746

Fawcett, L. L. E. (Ed.). (2016). International relations of the Middle East. Oxford University Press. Retrieved from https://doi.org/10.1093/hepl/9780198708742.001.0001

Hodson, D., \& Peterson, J. (Eds.). (2017). The institutions of the European Union. Oxford University Press. Retrieved from https://doi.org/10.1093/hep1/9780198737414.001.0001

IPU. (2021). Inter-Parliamentary Union/ Genesis of the IPU. Inter-Parliamentary Union. Retrieved from https://www.ipu.org/about-ipu/genesis-ipu.

Kinski, L. (2020). What role for national parliaments in EU governance? A view by members of parliament. Journal of European Integration, 1-22. Retrieved from https://doi.org/10.1080/07036337.2020.1817000

Luciano, B. T. (2017). Inter-parliamentary European Union-Latin American Caribbean (EU-LAC) relations and the increasing political convergence among Latin American regional parliaments (2006-15). Parliaments, Estates and Representation, 37(3), 318-334. Retrieved from https://doi.org/10.1080/02606755.2017.1336326

Mignolo, W. (2018). 1 REMEMBERING LA PATRIA GRANDE. Constituting Central American-Americans: Transnational Identities and the Politics of Dislocation, 23. Retrieved from https://doi.org/10.2307/j.ctt1vw0rx3.4

Moure, A. M. (2019). Cooperation between the European Parliament and the Parliament of MERCOSUR: strategic partnership towards interregionalism and effective multilateralism. In Parliamentary Cooperation and Diplomacy in EU External Relations. Edward Elgar Publishing. Retrieved from https://doi.org/10.4337/9781786438850.00031

Musliu, A. (2011). Parliament's role in prospering European integration and the relations between The Republic of Kosov and The Republic of Serbia. Retrieved from https://scholarworks.rit.edu/theses/7031

Palle, A., \& Richard, Y. (2021). Multilevel Governance or Scalar Clashes: Finding the Right Scale for EU Energy Policy. Tijdschrift voor economische en sociale geografie. Retrieved from https://doi.org/10.1111/tesg.12481

Richter, L. (2021). Moral Borderwork: Policies, Policing, and Practices of Migrant Smuggling at the EU-Morocco Border. Geopolitics, 1-20. Retrieved from https://doi.org/10.1080/14650045.2021.1953477

SICA. (2021). Central American Parliament - PARLACEN. Sica.int. Retrieved from https://www.sica.int/consulta/entidad.aspx? ?dEnt=827\&Idm=2\&IdmStyle=2.

Stout, M., \& Love, J. M. (2018). Integrative governance: Generating sustainable responses to global crises. Routledge. Retrieved from https://doi.org/10.1111/gove.12399 
Wagner, W. (2019). Rationales of inter-parliamentary cooperation in European security politics: from the Inter-Parliamentary Union to the IPC-CFSP. In Parliamentary Cooperation and Diplomacy in EU External Relations. Edward Elgar Publishing. Retrieved from https://doi.org/10.4337/9781786438850.00013

Yost, J. (2020). Creating a UN Parliamentary Assembly. In Building A More Democratic UNITED NATIONS (pp. 137-138). Routledge. Retrieved from https://doi.org/10.4324/9781003062493-27

\section{Copyrights}

Copyright for this article is retained by the author(s), with first publication rights granted to the journal.

This is an open-access article distributed under the terms and conditions of the Creative Commons Attribution license which permits unrestricted use, distribution, and reproduction in any medium, provided the original work is properly cited. 